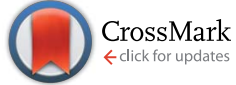
12404
Cite this: J. Mater. Chem. A, 2015, 3,

\section{Bottom-up and top-down methods to improve catalytic reactivity for photocatalytic production of hydrogen peroxide using a Ru-complex and water oxidation catalysts $\uparrow$}

\author{
Yusuke Isaka, ${ }^{a}$ Satoshi Kato, ${ }^{a}$ Dachao Hong, ${ }^{a}$ Tomoyoshi Suenobu, ${ }^{a}$ Yusuke Yamada ${ }^{a}$ \\ and Shunichi Fukuzumi ${ }^{* a b c}$
}

\begin{abstract}
Hydrogen peroxide $\left(\mathrm{H}_{2} \mathrm{O}_{2}\right)$ was produced from water and dioxygen using $\left[\mathrm{Ru}^{\prime \prime}\left(\mathrm{Me}_{2} \mathrm{phen}\right)_{3}\right]^{2+}\left(\mathrm{Me}_{2}\right.$ phen $=$ 4,7-dimethyl-1,10-phenanthroline) as a photocatalyst and $\left[\operatorname{lr}\left(\mathrm{Cp}^{*}\right)\left(\mathrm{H}_{2} \mathrm{O}\right)_{3}\right]^{2+}\left(\mathrm{Cp}^{*}=\eta^{5}\right.$ pentamethylcyclopentadienyl) as a precursor of a water oxidation catalyst in the presence of $\mathrm{Sc}^{3+}$ in water under visible light irradiation. TEM and XPS measurements of residues in the resulting solution after the photocatalytic production of $\mathrm{H}_{2} \mathrm{O}_{2}$ indicated that $\left[\operatorname{lr}\left(\mathrm{Cp}^{*}\right)\left(\mathrm{H}_{2} \mathrm{O}\right)_{3}\right]^{2+}$ was converted to $\operatorname{Ir}(\mathrm{OH})_{3}$ nanoparticles, which are actual catalytic species. The $\operatorname{Ir}(\mathrm{OH})_{3}$ nanoparticles produced in situ during the photocatalytic production of $\mathrm{H}_{2} \mathrm{O}_{2}$ were smaller in size than those prepared independently from hydrogen hexachloroiridiate $\left(\mathrm{H}_{2} \mid \mathrm{rCl}_{6}\right)$, and exhibited higher catalytic reactivity for the photocatalytic production of $\mathrm{H}_{2} \mathrm{O}_{2}$. The photocatalytic production of $\mathrm{H}_{2} \mathrm{O}_{2}$ from water and dioxygen was also made possible when $\operatorname{Ir}(\mathrm{OH})_{3}$ nanoparticles were replaced by nickel ferrite $\left(\mathrm{NiFe}_{2} \mathrm{O}_{4}\right)$ nanoparticles, which are composed of more earth abundant metals than iridium. The size of $\mathrm{NiFe}_{2} \mathrm{O}_{4}$ nanoparticles became smaller during the photocatalytic production of $\mathrm{H}_{2} \mathrm{O}_{2}$ to exhibit higher catalytic reactivity in the second run as compared with that in the first run. $\mathrm{NiFe}_{2} \mathrm{O}_{4}$ nanoparticles obtained by the treatment of $\mathrm{NiFe}_{2} \mathrm{O}_{4}$ in an aqueous solution of $\mathrm{Sc}^{3+}$ exhibited 33-times higher catalytic reactivity in $\mathrm{H}_{2} \mathrm{O}_{2}$-production rates than the as-prepared $\mathrm{NiFe}_{2} \mathrm{O}_{4}$. Thus, both the bottom-up method starting from a molecular complex $\left[\operatorname{lr}\left(\mathrm{Cp}^{*}\right)\left(\mathrm{H}_{2} \mathrm{O}\right)_{3}\right]^{2+}$ and the top-down method starting from as-prepared $\mathrm{NiFe}_{2} \mathrm{O}_{4}$ to obtain nanoparticles with smaller size resulted in the improvement of the catalytic reactivity for the photocatalytic production of $\mathrm{H}_{2} \mathrm{O}_{2}$ from water and dioxygen.
\end{abstract}

Received 4th April 2015

Accepted 23rd April 2015

DOI: $10.1039 / c 5 t a 02446 c$

www.rsc.org/MaterialsA

\section{Introduction}

The rapid and unsustainable use of fossil fuels has led to increased attention paid to the development of zero-carbon emission fuels, particularly hydrogen, utilizing renewable energy sources. ${ }^{\mathbf{1 - 7}}$ Solar energy is obviously the most abundant among the renewable energy sources under consideration. Thus, extensive efforts have been devoted to producing

\footnotetext{
${ }^{a}$ Department of Material and Life Science, Graduate School of Engineering, Osaka University, ALCA, SENTAN, Japan Science and Technology Agency (JST), Suita, Osaka 565-0871, Japan.E-mail: fukuzumi@chem.eng.osaka-u.ac.jp

${ }^{b}$ Faculty of Science and Engineering, Meijo University, ALCA, SENTAN, Japan Science and Technology Agency (JST), Nagoya, Aichi 468-0073, Japan

${ }^{c}$ Department of Bioinspired Science, Ewha Womans University, Seoul 120-750, Korea $\dagger$ Electronic supplementary information (ESI) available: Experimental section, time courses of $\mathrm{H}_{2} \mathrm{O}_{2}$ production under different conditions (Fig. S1, S2, S14-S17), TEM images (Fig. S3, S5 and S13), X-ray photoelectron spectra of $\mathrm{Ir}(\mathrm{OH})_{3}$ (Fig. S4), time course of $\mathrm{H}_{2} \mathrm{O}_{2}$ decomposition in the presence of $\mathrm{NiFe}_{2} \mathrm{O}_{4}$ (Fig. S6), DLS data (Fig. S7-S10), powder XRD patterns (Fig. S11), UV-Vis spectra (Fig. S12) and appendix for the derivation of specific surface area of particles. See DOI: $10.1039 / \mathrm{c} 5$ ta02446c
}

hydrogen by water splitting (eqn (1)), which is highly endergonic with a free energy change of $\Delta G^{\circ}=474 \mathrm{~kJ} \mathrm{~mol}^{-1}$, which is provided by solar energy. ${ }^{8-12}$ In this case, however, a method for separating the simultaneously produced $\mathrm{H}_{2}$ and $\mathrm{O}_{2}$ remains to be developed to avoid possible explosion. ${ }^{13}$ In addition, the storage of hydrogen at reasonable energy density poses a technical and economical challenge due to its low volumetric energy. ${ }^{14,15}$

$$
2 \mathrm{H}_{2} \mathrm{O} \rightarrow 2 \mathrm{H}_{2}+\mathrm{O}_{2} \quad \Delta G^{\circ}=474 \mathrm{~kJ} \mathrm{~mol}^{-1}
$$

In contrast to hydrogen, hydrogen peroxide $\left(\mathrm{H}_{2} \mathrm{O}_{2}\right)$ is miscible in water, and therefore it can be an ideal energy carrier alternative to hydrogen, because $\mathrm{H}_{2} \mathrm{O}_{2}$ can be used as a fuel for one-compartment fuel cells. ${ }^{16-23}$ The output potential of a $\mathrm{H}_{2} \mathrm{O}_{2}$ fuel cell theoretically achievable is $1.09 \mathrm{~V}$, which is comparable with that of a hydrogen fuel cell $(1.23 \mathrm{~V}) .{ }^{16,17}$ Thus, a combination of $\mathrm{H}_{2} \mathrm{O}_{2}$ production using solar energy and power generation with an $\mathrm{H}_{2} \mathrm{O}_{2}$ fuel cell provides an ideally sustainable solar fuel. ${ }^{16,17}$ It is desired to produce $\mathrm{H}_{2} \mathrm{O}_{2}$ from $\mathrm{H}_{2} \mathrm{O}$ and $\mathrm{O}_{2}$ (eqn (2)), 
which is highly endergonic with the free energy change of $\Delta G^{\circ}=$ $210 \mathrm{~kJ} \mathrm{~mol}^{-1}$, by using solar energy. ${ }^{16,17}$

$2 \mathrm{H}_{2} \mathrm{O}+\mathrm{O}_{2} \rightarrow 2 \mathrm{H}_{2} \mathrm{O}_{2} \quad \Delta G^{\circ}=210 \mathrm{~kJ} \mathrm{~mol}^{-1}$

We have recently reported the photocatalytic production of $\mathrm{H}_{2} \mathrm{O}_{2}$ from $\mathrm{H}_{2} \mathrm{O}$ and $\mathrm{O}_{2}$ by combining the photoreduction of $\mathrm{O}_{2}$ with a Ru-complex photosensitiser and water oxidation with $\operatorname{Ir}(\mathrm{OH})_{3}$ nanoparticles as water oxidation catalysts (WOCs) in the presence of $\mathrm{Sc}^{3+}$ in water under visible light irradiation. ${ }^{24}$ In order to improve the photocatalytic reactivity of $\mathrm{H}_{2} \mathrm{O}_{2}$ production from $\mathrm{H}_{2} \mathrm{O}$ and $\mathrm{O}_{2}$, it is required to employ more efficient WOCs. Extensive efforts have so far been devoted to developing efficient WOCs using transition metal complexes..$^{25-45}$ In particular, a series of mononuclear iridium(III) complexes with the $\eta^{5}$-pentamethylcyclopentadienyl ligand $\left(\mathrm{Cp}^{*}\right)$ have been reported to act as efficient WOCs, which are more active than ruthenium complexes. ${ }^{46-49}$ The $\mathrm{Cp}^{*}$ ligand is expected to provide electron rich circumstances useful to stabilise reaction intermediates possessing a high-valent oxidation state in catalytic water oxidation by cerium ammonium nitrate, $\left(\mathrm{NH}_{4}\right)_{2}\left[\mathrm{Ce}\left(\mathrm{NO}_{3}\right)_{6}\right]$, (CAN) ${ }^{46-49}$ Under the conditions of catalytic water oxidation by CAN, however, the $\mathrm{Cp}^{*}$ ligand of Ir complexes has been reported to be oxidised to produce $\operatorname{IrO}_{2}$ or $\operatorname{Ir}(\mathrm{OH})_{3}$ nanoparticles, which act as the actual reactive catalyst for water oxidation. ${ }^{50-54} \mathrm{IrO}_{2}$ or $\operatorname{Ir}(\mathrm{OH})_{3}$ nanoparticles have been reported to be more active than conventional $\mathrm{IrO}_{2}$ prepared from $\mathrm{H}_{2} \mathrm{IrCl}_{6}{ }^{55-61}$ Thus, in situ formation of a WOC provides a useful way to improve the catalytic reactivity for water oxidation.

We report herein the photocatalytic production of $\mathrm{H}_{2} \mathrm{O}_{2}$ from $\mathrm{H}_{2} \mathrm{O}$ and $\mathrm{O}_{2}$ using an Ir complex, $\left[\operatorname{Ir}\left(\mathrm{Cp}^{*}\right)\left(\mathrm{H}_{2} \mathrm{O}\right)_{3}\right]^{2+}$, as a precursor of a water oxidation catalyst and $\left[\mathrm{Ru}^{\mathrm{II}}\left(\mathrm{Me}_{2} \mathrm{phen}\right)_{3}\right]^{2+}$ $\left(\mathrm{Me}_{2}\right.$ phen $=4,7$-dimethyl-1,10-phenanthroline $)$ as a homogeneous photocatalyst in the presence of $\mathrm{Sc}^{3+}$ in water. The characterisation of the catalytically active species has revealed that $\left[\operatorname{Ir}\left(\mathrm{Cp}^{*}\right)\left(\mathrm{H}_{2} \mathrm{O}\right)_{3}\right]^{2+}$ is converted to $\operatorname{Ir}(\mathrm{OH})_{3}$ nanoparticles, which exhibit high catalytic reactivity for photocatalytic water oxidation. A synthetic strategy for such $\operatorname{Ir}(\mathrm{OH})_{3}$ nanoparticles from $\mathrm{H}_{2} \mathrm{IrCl}_{6}$ has not yet been established. Because Ir is a noble metal with limited natural supplies, it is desired to replace the noble metal in WOCs by more earth-abundant metals such as Fe and $\mathrm{Ni}$. In this context, we have also employed nanoparticles composed of earth abundant nickel and iron $\left(\mathrm{NiFe}_{2} \mathrm{O}_{4}\right)$ instead of the Ir complex as a water oxidation catalyst for the photocatalytic production of $\mathrm{H}_{2} \mathrm{O}_{2}$. During the reaction, $\mathrm{NiFe}_{2} \mathrm{O}_{4}$ nanoparticles were formed from the corresponding as-prepared $\mathrm{NiFe}_{2} \mathrm{O}_{4}$. The effect of reaction conditions on the reactivity of the therein-formed nanoparticles from the Ir complex or $\mathrm{NiFe}_{2} \mathrm{O}_{4}$ is discussed in this paper.

\section{Results and discussion}

\section{Photocatalytic production of hydrogen peroxide with an iridium complex precatalyst}

The photocatalytic production of $\mathrm{H}_{2} \mathrm{O}_{2}$ was performed using $\left[\mathrm{Ru}^{\mathrm{II}}\left(\mathrm{Me}_{2} \text { phen }\right)_{3}\right]^{2+}$ as a photocatalyst for the two-electron reduction of $\mathrm{O}_{2}$ and various Ir compounds as WOCs in the presence of $\mathrm{Sc}^{3+}$ ions in distilled water as shown in Fig. 1a. $\mathrm{Sc}^{3+}$ ions were reported to prohibit back electron transfer from $\mathrm{O}_{2}{ }^{\cdot-}$ to $\left[\mathrm{Ru}^{\mathrm{III}}\left(\mathrm{Me}_{2} \mathrm{phen}\right)_{3}\right]^{3+}$, which is formed after photoinduced electron transfer to $\mathrm{O}_{2}$ from an excited state of $\left[\mathrm{Ru}^{\mathrm{II}}\left(\mathrm{Me}_{2}-\right.\right.$ phen $\left.)_{3}\right]^{2+}$ (vide infra). ${ }^{24}$ The initial rate of $\mathrm{H}_{2} \mathrm{O}_{2}$ production using $\left[\operatorname{Ir}\left(\mathrm{Cp}^{*}\right)\left(\mathrm{H}_{2} \mathrm{O}\right)_{3}\right]^{2+}$ (red squares in Fig. 1a) was 4.5 times faster than that using $\operatorname{Ir}(\mathrm{OH})_{3}$ nanoparticles (blue circles in Fig. 1a) prepared from $\mathrm{H}_{2} \mathrm{IrCl}_{6}$ with the same amount of Ir. ${ }^{54}$ The rate of $\mathrm{H}_{2} \mathrm{O}_{2}$ production using $\left[\mathrm{Ir}\left(\mathrm{Cp}^{*}\right)\left(\mathrm{H}_{2} \mathrm{O}\right)_{3}\right]^{2+}$ was 4.4 times and 2.8 times faster than those using $\operatorname{Ir}\left(\mathrm{SO}_{4}\right)_{2}$ and $\left[\operatorname{Ir}(\mathrm{Cp} *)\left((\mathrm{OH})_{2}-\right.\right.$ bpy $\left.)\left(\mathrm{H}_{2} \mathrm{O}\right)\right]^{2+}\left((\mathrm{OH})_{2}\right.$ bpy $=4,4^{\prime}-(\mathrm{OH})_{2}-2,2^{\prime}$-bipyridine $)$, respectively. $\left[\operatorname{Ir}\left(\mathrm{Cp}^{*}\right)\left(\mathrm{H}_{2} \mathrm{O}\right)_{3}\right]^{2+}$ had higher reactivity than Co complexes and Co ions, which have been reported to act as highly active WOCs, as shown in Fig. 1b. ${ }^{62,63}$ The quantum efficiency determined by using monochromatised light $(450 \mathrm{~nm})$ and the solar energy conversion efficiency of the production of $\mathrm{H}_{2} \mathrm{O}_{2}$ were determined to be $7.1 \%$ and $0.063 \%$, respectively (Fig. S1 and S2 $\dagger$ ). The sigmoidal behaviour in the initial stage of $\mathrm{H}_{2} \mathrm{O}_{2}$ production with $\left[\operatorname{Ir}\left(\mathrm{Cp}^{*}\right)\left(\mathrm{H}_{2} \mathrm{O}\right)_{3}\right]^{2+}$ (Fig. 2, green) indicates that $\left[\operatorname{Ir}\left(\mathrm{Cp}^{*}\right)\left(\mathrm{H}_{2} \mathrm{O}\right)_{3}\right]^{2+}$ acts as a precatalyst to produce catalytically more active species during the photocatalytic production of $\mathrm{H}_{2} \mathrm{O}_{2}$.

The sigmoidal behaviour was more pronounced when the photocatalytic production of $\mathrm{H}_{2} \mathrm{O}_{2}$ was performed at $278 \mathrm{~K}$ as shown in Fig. 2 (red circles), where the results at higher temperatures are compared. The initial rate of $\mathrm{H}_{2} \mathrm{O}_{2}$ production increases with increasing temperature (Fig. 2), but the maximum $\mathrm{H}_{2} \mathrm{O}_{2}$ concentration decreased because of the enhanced decomposition of $\mathrm{H}_{2} \mathrm{O}_{2}$.

The formation of nanoparticles was observed by transmission electron microscopy (TEM) measurements. TEM images of the particles (Fig. S3†) showed that the diameters of the particles increased by extending the reaction time. The formation of nanoparticles was also confirmed by dynamic light scattering (DLS) measurements as shown in Fig. 3. The size of nanoparticles formed after $12 \mathrm{~h}$ photoirradiation at $278 \mathrm{~K}$ was $21 \mathrm{~nm}$, whereas the size increased to $240 \mathrm{~nm}$ after $36 \mathrm{~h}$
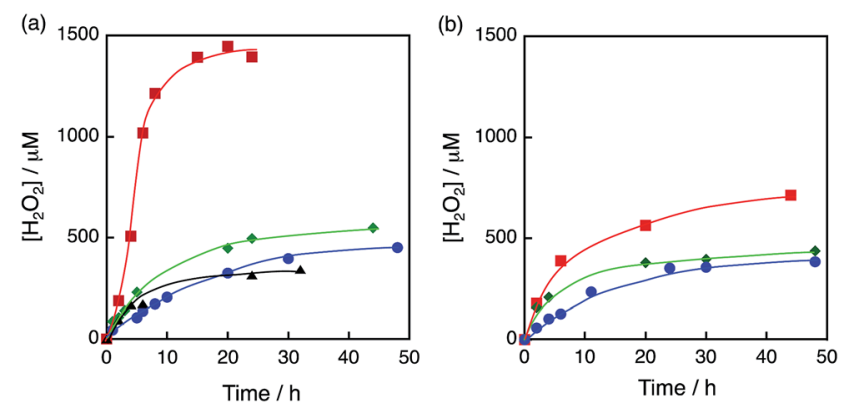

Fig. 1 Time courses of $\mathrm{H}_{2} \mathrm{O}_{2}$ production under visible light $(\lambda>420$ $\mathrm{nm})$ irradiation of $\left[\mathrm{Ru}^{\prime \prime}\left(\mathrm{Me}_{2} \text { phen }\right)_{3}\right]^{2+}(2 \mathrm{O} \mu \mathrm{M})$ in the presence of $\mathrm{Sc}^{3+}$ $(100 \mathrm{mM})$ in $\mathrm{O}_{2}$-saturated $\mathrm{H}_{2} \mathrm{O}\left(3.0 \mathrm{~mL},\left[\mathrm{O}_{2}\right]=1.2 \mathrm{mM}\right)$ containing (a) various Ir compounds, $\left[\operatorname{Ir}(\mathrm{Cp} *)\left(\mathrm{H}_{2} \mathrm{O}\right)_{3}\right]^{2+}$ (red squares), $\left[\operatorname{Ir}(\mathrm{Cp} *)\left((\mathrm{OH})_{2^{-}}\right.\right.$ bpy) $\left.\left(\mathrm{H}_{2} \mathrm{O}\right)\right]^{2+}$ (green diamonds), $\operatorname{lr}(\mathrm{OH})_{3}$ (blue circles) and $\operatorname{Ir}\left(\mathrm{SO}_{4}\right)$ (black triangles), where Ir content: $100 \mu \mathrm{M}$ and (b) various Co compounds, $\left[\mathrm{Co}(\mathrm{Cp} *)(\mathrm{bpy})\left(\mathrm{H}_{2} \mathrm{O}\right)\right]^{2+}$ (red squares), $\left[\mathrm{Co}(\mathrm{Cp} *)\left(\mathrm{H}_{2} \mathrm{O}\right)_{3}\right]^{2+}$ (green diamonds) and $\mathrm{Co}\left(\mathrm{NO}_{3}\right)_{3}$ (blue circles), where Co content: $100 \mu \mathrm{M}$ at $298 \mathrm{~K}$. 


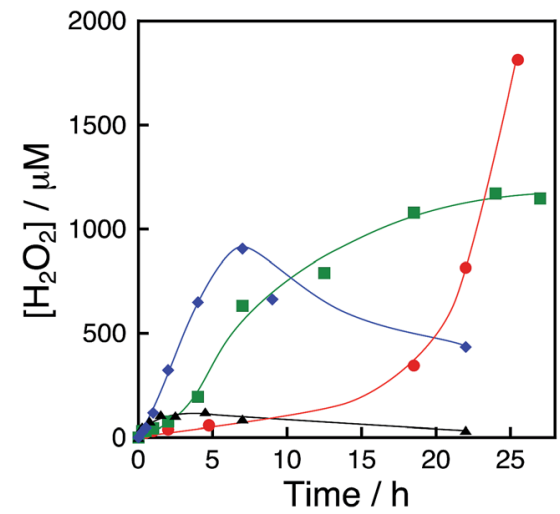

Fig. 2 Time courses of $\mathrm{H}_{2} \mathrm{O}_{2}$ production under visible light $(\lambda>420$ $\mathrm{nm})$ irradiation of $\left[\mathrm{Ru}^{\prime \prime}\left(\mathrm{Me}_{2} \text { phen }\right)_{3}\right]^{2+}(20 \mu \mathrm{M})$ in the presence of $\left[\operatorname{Ir}(\mathrm{Cp} *)\left(\mathrm{H}_{2} \mathrm{O}\right)_{3}\right]^{2+}(100 \mu \mathrm{M})$ and $\mathrm{Sc}^{3+}(100 \mathrm{mM})$ in an $\mathrm{O}_{2}$-saturated aqueous solution $(3.0 \mathrm{~mL}$ ) at $333 \mathrm{~K}$ (black triangles), $313 \mathrm{~K}$ (blue diamonds), $293 \mathrm{~K}$ (green squares) and $278 \mathrm{~K}$ (red circles).

(a)

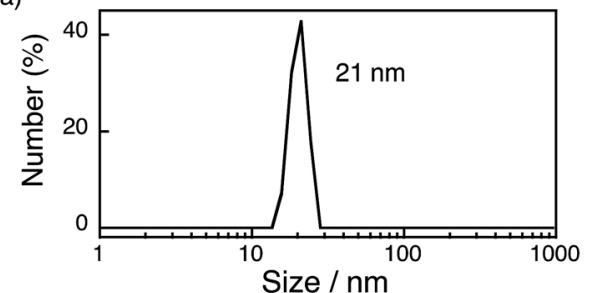

(b)

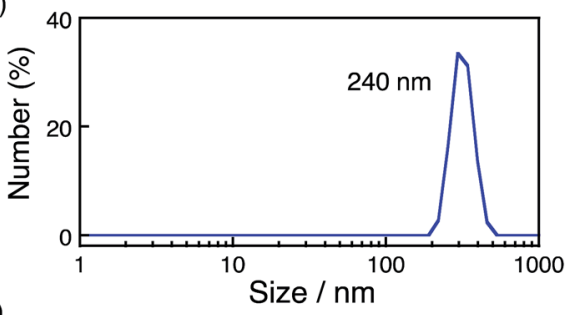

(c)

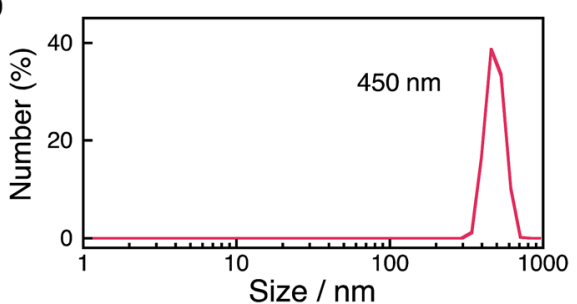

Fig. 3 Size distributions of the particles obtained by DLS measurements. The particles were formed under visible light $(\lambda>420 \mathrm{~nm})$ irradiation of $\left[\mathrm{Ru}^{\mathrm{II}}\left(\mathrm{Me}_{2} \text { phen }\right)_{3}\right]^{2+}(20 \mu \mathrm{M})$ in the presence of $\left[\operatorname{lr}(\mathrm{Cp} *)\left(\mathrm{H}_{2} \mathrm{O}\right)_{3}\right]^{2+}(100 \mu \mathrm{M})$ and $\mathrm{Sc}^{3+}(100 \mathrm{mM})$ in an $\mathrm{O}_{2}$-saturated aqueous solution ( $3.0 \mathrm{~mL}$ ) at $298 \mathrm{~K}$ for (a) $12 \mathrm{~h}$, (b) $36 \mathrm{~h}$ and (c) at $333 \mathrm{~K}$ for $12 \mathrm{~h}$.

photoirradiation. Large-sized particles $(450 \mathrm{~nm})$ were obtained after $12 \mathrm{~h}$ photoirradiation at $333 \mathrm{~K}$. Thus, the size of the particles depends on the photoirradiation time and temperature. During photocatalytic $\mathrm{H}_{2} \mathrm{O}_{2}$ production, the size of the nanoparticles $(21 \mathrm{~nm}$ ) increases to $240 \mathrm{~nm}$ after $36 \mathrm{~h}$ (Fig. 3a and b) and the rate of the reaction decreases (Fig. 2, green line) under irradiation of visible light at room temperature. The deceleration of the reaction rate may be ascribed to the decrease in the surface area of the nanoparticles with increasing the size of the nanoparticles. $\left[\operatorname{Ir}\left(\mathrm{Cp}^{*}\right)\left(\mathrm{H}_{2} \mathrm{O}\right)_{3}\right]^{2+}$ has been reported to be efficiently oxidised by CAN, and TG/DTA and XPS measurements of nanoparticles produced after the water oxidation suggested that the nanoparticles were composed of $\operatorname{Ir}(\mathrm{OH})_{3}{ }^{.1}$ XPS measurements of the nanoparticles centrifugally recovered from the reaction solution after the $\mathrm{H}_{2} \mathrm{O}_{2}$ production reaction were performed for the energy regions of Ir $4 \mathrm{f}, \mathrm{O} 1 \mathrm{~s}$ and $\mathrm{C} 1 \mathrm{~s}$ with reference to commercially available $\mathrm{IrO}_{2}$ (Fig. S4 $\dagger$ ), which suggested that the formed nanoparticles are also composed of $\operatorname{Ir}(\mathrm{OH})_{3}$. Since the binding energy of $\operatorname{Ir} 4 \mathrm{f}_{5 / 2}$ reflects the valence of Ir ions, the value was determined to be $61.9 \mathrm{eV}$ for $\operatorname{Ir}(\mathrm{OH})_{3}$ nanoparticles, which is close to the reported value for Ir II $^{\text {II }}$ $(62.0 \mathrm{eV}) .^{62}$ These values were significantly different from those for $\operatorname{Ir}^{0}(61.0 \mathrm{eV})$ or $\operatorname{Ir}^{\mathrm{IV}}(63.7 \mathrm{eV}){ }^{58,62-67}$ The binding energy for $\mathrm{O}$ 1s of $\operatorname{Ir}(\mathrm{OH})_{3}$ nanoparticles (531.9 eV) shifted from that of $\mathrm{IrO}_{2}$ $(530.2 \mathrm{eV})$ due to the $\mathrm{OH}$ moiety as reported previously. ${ }^{54}$ TEM images of $\operatorname{Ir}(\mathrm{OH})_{3}$ nanoparticles revealed that the size of $\operatorname{Ir}(\mathrm{OH})_{3}$ nanoparticles $(10-20 \mathrm{~nm})$ derived from $\left[\operatorname{Ir}\left(\mathrm{Cp}^{*}\right)\left(\mathrm{H}_{2} \mathrm{O}\right)_{3}\right]^{2+}$ was
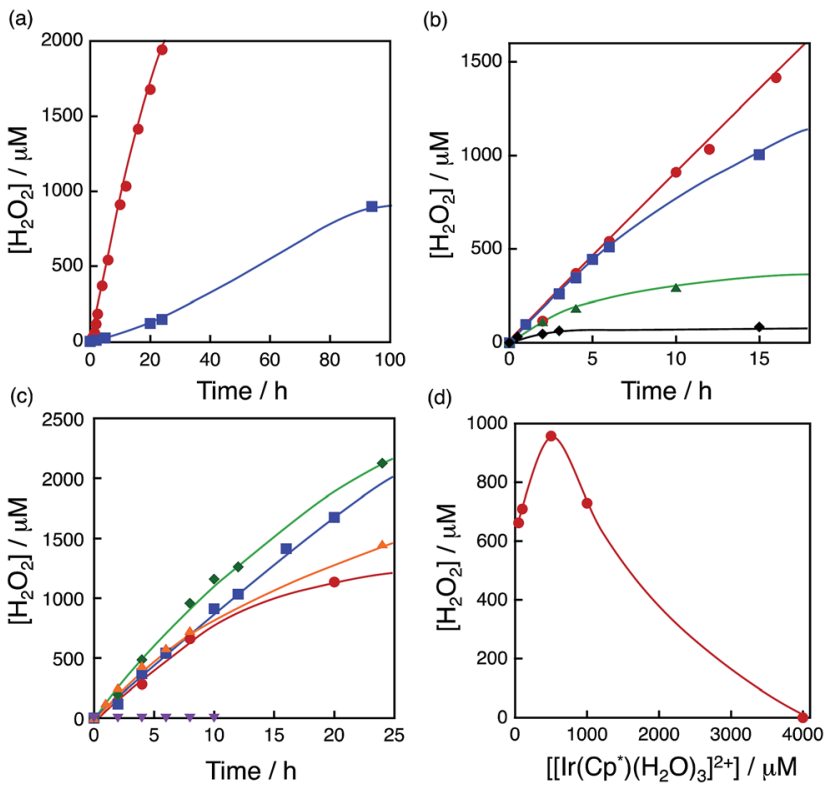

Fig. 4 (a) Time courses of $\mathrm{H}_{2} \mathrm{O}_{2}$ production at different concentrations of $\left[\mathrm{Ru}^{\prime \prime}\left(\mathrm{Me}_{2} \text { phen) }\right]_{3}^{2+}[20 \mu \mathrm{M}\right.$ (red circles) and $1.0 \mu \mathrm{M}$ (blue squares) $)$ under irradiation of $\left[\mathrm{Ru}^{\prime \prime}\left(\mathrm{Me}_{2} \text { phen }\right)_{3}\right]^{2+}$ with visible light $(\lambda>$ $420 \mathrm{~nm})$ in the presence of $\left[\operatorname{Ir}(\mathrm{Cp} *)\left(\mathrm{H}_{2} \mathrm{O}\right)_{3}\right]^{2+}(100 \mu \mathrm{M})$ and $\mathrm{Sc}^{3+}(100$ $\mathrm{mM})$ in $\mathrm{O}_{2}$-saturated $\mathrm{H}_{2} \mathrm{O}\left(3.0 \mathrm{~mL},\left[\mathrm{O}_{2}\right]=1.2 \mathrm{mM}\right)$ at $298 \mathrm{~K}$. (b) Time courses of $\mathrm{H}_{2} \mathrm{O}_{2}$ production at different concentrations of $\mathrm{Sc}^{3+}[0 \mathrm{mM}$ (black diamonds), $1.0 \mathrm{mM}$ (green triangles), $10 \mathrm{mM}$ (blue squares) and $100 \mathrm{mM}$ (red circles)] under irradiation of $\left[\mathrm{Ru}^{\prime \prime}\left(\mathrm{Me}_{2} \text { phen }\right)_{3}\right]^{2+}(20 \mu \mathrm{M})$ with visible light $(\lambda>420 \mathrm{~nm})$ in the presence of $\left[\operatorname{lr}(\mathrm{Cp} *)\left(\mathrm{H}_{2} \mathrm{O}\right)_{3}\right]^{2+}(100$ $\mu \mathrm{M})$ in $\mathrm{O}_{2}$-saturated $\mathrm{H}_{2} \mathrm{O}\left(3.0 \mathrm{~mL},\left[\mathrm{O}_{2}\right]=1.2 \mathrm{mM}\right)$ at $298 \mathrm{~K}$. (c) Time courses of $\mathrm{H}_{2} \mathrm{O}_{2}$ production at different concentrations of $\left[\operatorname{lr}(\mathrm{Cp} *)\left(\mathrm{H}_{2} \mathrm{O}\right)_{3}\right]^{2+}[50 \mu \mathrm{M}$ (red circles), $100 \mu \mathrm{M}$ (blue squares), $500 \mu \mathrm{M}$ (green diamonds), $1000 \mu \mathrm{M}$ (orange triangles) and $4000 \mu \mathrm{M}$ (purple inverse triangles)] at $298 \mathrm{~K}$. (d) Plot of the amount of $\mathrm{H}_{2} \mathrm{O}_{2}$ production after $8 \mathrm{~h}$ vs. the concentration of $\left[\mathrm{Ir}(\mathrm{Cp} *)\left(\mathrm{H}_{2} \mathrm{O}\right)_{3}\right]^{2+}$ under irradiation of $\left[\mathrm{Ru}^{\prime \prime}\left(\mathrm{Me}_{2} \text { phen }\right)_{3}\right]^{2+}(20 \mu \mathrm{M})$ with visible light $(\lambda>420 \mathrm{~nm})$ in the presence of $\mathrm{Sc}^{3+}(100 \mathrm{mM})$ in $\mathrm{O}_{2}$-saturated $\mathrm{H}_{2} \mathrm{O}\left(3.0 \mathrm{~mL},\left[\mathrm{O}_{2}\right]=1.2 \mathrm{mM}\right)$ at $298 \mathrm{~K}$. 
smaller than that of $\operatorname{Ir}(\mathrm{OH})_{3}(30-100 \mathrm{~nm})$ derived from $\mathrm{H}_{2} \mathrm{IrCl}_{6}$ (Fig. S5 $\dagger$ ). The higher catalytic reactivity of $\operatorname{Ir}(\mathrm{OH})_{3}$ nanoparticles derived from $\left[\operatorname{Ir}\left(\mathrm{Cp}^{*}\right)\left(\mathrm{H}_{2} \mathrm{O}\right)_{3}\right]^{2+}$ may result from the smaller size of the nanoparticles as compared with those derived from $\mathrm{H}_{2} \mathrm{IrCl}_{6}$.

The dependence of photocatalytic reactivity for $\mathrm{H}_{2} \mathrm{O}_{2}$ production on the concentration of $\left[\mathrm{Ru}^{\mathrm{II}}\left(\mathrm{Me}_{2} \text { phen }\right)_{3}\right]^{2+}$ was examined as shown in Fig. 4a. The photocatalytic reactivity decreased with decreasing the concentration of $\left[\mathrm{Ru}^{\mathrm{II}}\left(\mathrm{Me}_{2} \text { phen }\right)_{3}\right]^{2+}$, however, the highest TON based on $\left[\mathrm{Ru}^{\mathrm{II}}\left(\mathrm{Me}_{2} \text { phen }\right)_{3}\right]^{2+}$ was determined to be 898 after $94 \mathrm{~h}$ photoirradiation when the concentration of $\left[\mathrm{Ru}^{\mathrm{II}}\left(\mathrm{Me}_{2} \text { phen }\right)_{3}\right]^{2+}$ was reduced to $1.0 \mu \mathrm{M}$, which is much higher than that reported for the photocatalytic $\mathrm{H}_{2} \mathrm{O}_{2}$ production using $\operatorname{Ir}(\mathrm{OH})_{3}$ as a WOC (307). ${ }^{24}$

The dependence of photocatalytic reactivity for $\mathrm{H}_{2} \mathrm{O}_{2}$ production on the concentration of $\mathrm{Sc}^{3+}$ was also examined as shown in Fig. 4b. The photocatalytic reactivity increased with increasing the concentration of $\mathrm{Sc}^{3+}$. This is because $\mathrm{Sc}^{3+}$ inhibits back electron transfer from $\mathrm{O}_{2}{ }^{\cdot-}$ to $\left[\mathrm{Ru}^{\mathrm{III}}\left(\mathrm{Me}_{2} \text { phen }\right)_{3}\right]^{3+}$, which is generated by photoinduced electron transfer from the excited state of $\left[\mathrm{Ru}^{\mathrm{II}}\left(\mathrm{Me}_{2} \text { phen }\right)_{3}\right]^{2+}$ to $\mathrm{O}_{2}$ as reported previously. ${ }^{24}$

The dependence of photocatalytic reactivity of $\mathrm{H}_{2} \mathrm{O}_{2}$ production on the concentration of $\left[\operatorname{Ir}\left(\mathrm{Cp}^{*}\right)\left(\mathrm{H}_{2} \mathrm{O}\right)_{3}\right]^{2+}$ is shown in Fig. 4c. The highest TON based on $\left[\operatorname{Ir}\left(\mathrm{Cp}^{*}\right)\left(\mathrm{H}_{2} \mathrm{O}\right)_{3}\right]^{2+}$ was determined to be 23 after $20 \mathrm{~h}$ photoirradiation when $50 \mu \mathrm{M}$ of $\left[\operatorname{Ir}\left(\mathrm{Cp}^{*}\right)\left(\mathrm{H}_{2} \mathrm{O}\right)_{3}\right]^{2+}$ was employed in the photocatalytic $\mathrm{H}_{2} \mathrm{O}_{2}$ production. The photocatalytic reactivity increased with increasing concentration of $\left[\operatorname{Ir}\left(\mathrm{Cp}^{*}\right)\left(\mathrm{H}_{2} \mathrm{O}\right)_{3}\right]^{2+}$, but it decreased through the maximum value with further increase in the concentration of $\left[\operatorname{Ir}\left(\mathrm{Cp}^{*}\right)\left(\mathrm{H}_{2} \mathrm{O}\right)_{3}\right]^{2+}$ as shown in Fig. 4d. The decrease in the rate of $\mathrm{H}_{2} \mathrm{O}_{2}$ production may result from the catalytic decomposition of $\mathrm{H}_{2} \mathrm{O}_{2}$ with $\left[\operatorname{Ir}\left(\mathrm{Cp}^{*}\right)\left(\mathrm{H}_{2} \mathrm{O}\right)_{3}\right]^{2+}$ as shown in Fig. 5a. When a high concentration of $\left[\operatorname{Ir}(\mathrm{Cp} *)\left(\mathrm{H}_{2} \mathrm{O}\right)_{3}\right]^{2+}$ (e.g., $1000 \mu \mathrm{M})$ was employed in the photocatalytic production of $\mathrm{H}_{2} \mathrm{O}_{2}$, a part of $\left[\operatorname{Ir}\left(\mathrm{Cp}^{*}\right)\left(\mathrm{H}_{2} \mathrm{O}\right)_{3}\right]^{2+}$ may remain without the full conversion to $\operatorname{Ir}(\mathrm{OH})_{3}$ nanoparticles. When a low concentration
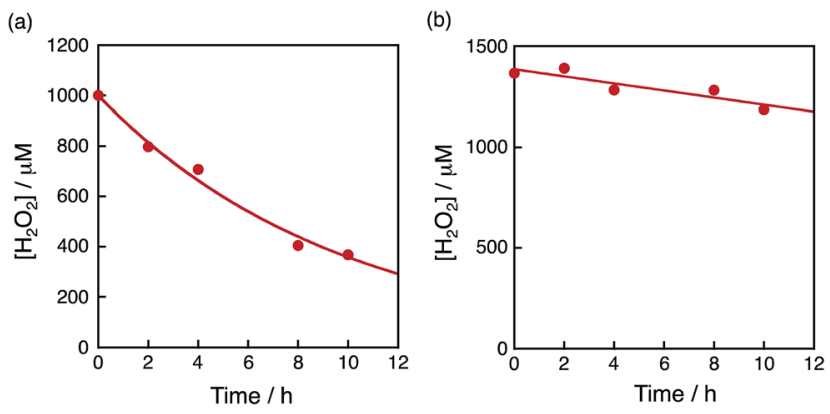

Fig. 5 Time course of the concentration of $\mathrm{H}_{2} \mathrm{O}_{2}$ in the presence of (a) $\left[\operatorname{lr}(\mathrm{Cp} *)\left(\mathrm{H}_{2} \mathrm{O}\right)_{3}\right]^{2+}(100 \mu \mathrm{M})$ and $(\mathrm{b})$ the $\operatorname{Ir}(\mathrm{OH})_{3}$ nanoparticles in $\mathrm{H}_{2} \mathrm{O}$ $(3.0 \mathrm{~mL})$ at $298 \mathrm{~K}$ containing $\mathrm{H}_{2} \mathrm{O}_{2}$ and $\mathrm{Sc}^{3+}(100 \mathrm{mM})$ under dark conditions. The $\operatorname{Ir}(\mathrm{OH})_{3}$ nanoparticles used were formed after $16 \mathrm{~h}$ photoirradiation of $\left[\mathrm{Ru}^{\prime \prime}\left(\mathrm{Me}_{2} \mathrm{phen}_{3}\right]^{2+}(20 \mu \mathrm{M})\right.$ with visible light $(\lambda>420$ $\mathrm{nm})$ in the presence of $\left[\operatorname{Ir}(\mathrm{Cp} *)\left(\mathrm{H}_{2} \mathrm{O}\right)_{3}\right]^{2+}(100 \mu \mathrm{M})$ and $\mathrm{Sc}^{3+}(100 \mathrm{mM})$ in $\mathrm{O}_{2}$-saturated $\mathrm{H}_{2} \mathrm{O}\left(3.0 \mathrm{~mL},\left[\mathrm{O}_{2}\right]=1.2 \mathrm{mM}\right)$ at $298 \mathrm{~K}$ and the resulting aqueous suspension was used as is for the measurements. of $\left[\operatorname{Ir}\left(\mathrm{Cp}^{*}\right)\left(\mathrm{H}_{2} \mathrm{O}\right)_{3}\right]^{2+}$ was employed, all of the $\left[\operatorname{Ir}\left(\mathrm{Cp}^{*}\right)\left(\mathrm{H}_{2} \mathrm{O}\right)_{3}\right]^{2+}$ may be oxidised to produce $\operatorname{Ir}(\mathrm{OH})_{3}$ nanoparticles during the photocatalytic reaction. The formed $\operatorname{Ir}(\mathrm{OH})_{3}$ nanoparticles are less reactive toward $\mathrm{H}_{2} \mathrm{O}_{2}$ decomposition as compared to $\left[\operatorname{Ir}\left(\mathrm{Cp}^{*}\right)\left(\mathrm{H}_{2} \mathrm{O}\right)_{3}\right]^{2+}\left(\right.$ Fig. 5). The conversion of $\left[\operatorname{Ir}\left(\mathrm{Cp}^{*}\right)\left(\mathrm{H}_{2} \mathrm{O}\right)_{3}\right]^{2+}$ to $\mathrm{Ir}(\mathrm{OH})_{3}$ during the photocatalytic production of $\mathrm{H}_{2} \mathrm{O}_{2}$ may be associated with the oxidation of the $\mathrm{Cp}^{*}$ ligand by $\mathrm{O}_{2}$. The full oxidation of $\mathrm{Cp}^{*}$ is expected to produce 10 equivalents of $\mathrm{CO}_{2}$ and 8 equivalents of $\mathrm{H}_{2} \mathrm{O}_{2}$ (eqn (3)). During the photocatalytic production of $\mathrm{H}_{2} \mathrm{O}_{2}, \mathrm{CO}_{2}$ evolution was observed as shown in Fig. 6a. However, the yield of $\mathrm{CO}_{2}$ based on eqn (3) is only $1 \%$. Thus, the $\mathrm{Cp}^{*}$ ligand is only partially oxidised to $\mathrm{CO}_{2}$. The amount of $\mathrm{H}_{2} \mathrm{O}_{2}$ that is expected to be produced from $\mathrm{Cp}$ * calculated based on eqn (3) [Fig. 6b (blue line)] was negligible as compared with the observed amount of $\mathrm{H}_{2} \mathrm{O}_{2}$ in Fig. 6b (red line). These results indicate that $\mathrm{H}_{2} \mathrm{O}_{2}$ was produced by using $\mathrm{H}_{2} \mathrm{O}$ as an electron source.

$$
\mathrm{C}_{10} \mathrm{H}_{15}{ }^{-}+18 \mathrm{O}_{2}+\mathrm{H}^{+} \rightarrow 10 \mathrm{CO}_{2}+8 \mathrm{H}_{2} \mathrm{O}_{2}
$$

\section{Photocatalytic production of hydrogen peroxide with $\mathrm{NiFe}_{2} \mathrm{O}_{4}$ nanoparticles}

The catalytic reactivity of nickel ferrite $\left(\mathrm{NiFe}_{2} \mathrm{O}_{4}\right)$ for water oxidation has been reported to be comparable to that of a catalyst containing Ir, Ru or Co in terms of the oxygen yield and oxygen-evolving rate under ambient reaction conditions. ${ }^{67}$

Because $\mathrm{NiFe}_{2} \mathrm{O}_{4}$ is composed of much more earth-abundant metals than Ir, $\mathrm{NiFe}_{2} \mathrm{O}_{4}$ was employed as a WOC for the photocatalytic production of $\mathrm{H}_{2} \mathrm{O}_{2}$ with $\left[\mathrm{Ru}^{\mathrm{II}}\left(\mathrm{Me}_{2} \text { phen }\right)_{3}\right]^{2+}$ in the presence of $\mathrm{Sc}^{3+}$ in water. The overall photocatalytic cycle for $\mathrm{H}_{2} \mathrm{O}_{2}$ production is depicted in Scheme 1. Photoinduced electron transfer from the excited state of $\left[\mathrm{Ru}^{\mathrm{II}}\left(\mathrm{Me}_{2} \text { phen }\right)_{3}\right]^{2+}$ to $\mathrm{O}_{2}$ results in the formation of $\mathrm{H}_{2} \mathrm{O}_{2}$ and $\left[\mathrm{Ru}^{\mathrm{III}}\left(\mathrm{Me}_{2} \text { phen }\right)_{3}\right]^{3+}$ via the oxidation of $\mathrm{NiFe}_{2} \mathrm{O}_{4}$, which oxidises water to form $\mathrm{O}_{2}$ and $\left[\mathrm{Ru}^{\mathrm{II}}\left(\mathrm{Me}_{2} \text { phen }\right)_{3}\right]^{2+}$. Back electron transfer from $\mathrm{O}_{2}{ }^{\cdot-}$ to
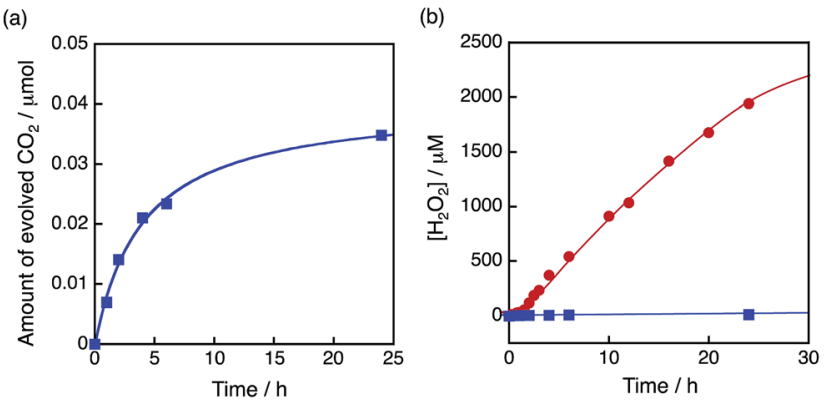

Fig. 6 (a) Time course of $\mathrm{CO}_{2}$ evolution at $298 \mathrm{~K}$ under visible light $(\lambda>$ $420 \mathrm{~nm})$ irradiation of $\left[\mathrm{Ru}^{\prime \prime}\left(\mathrm{Me}_{2} \text { phen }\right)_{3}\right]^{2+}(20 \mu \mathrm{M})$ in the presence of $\mathrm{Sc}^{3+}(100 \mathrm{mM})$ in $\mathrm{O}_{2}$-saturated $\mathrm{H}_{2} \mathrm{O}\left(3.0 \mathrm{~mL},\left[\mathrm{O}_{2}\right]=1.2 \mathrm{mM}\right)$ containing $\left[\operatorname{lr}(\mathrm{Cp} *)\left(\mathrm{H}_{2} \mathrm{O}\right)_{3}\right]^{2+}(100 \mu \mathrm{M})$. (b) Time course of $\mathrm{H}_{2} \mathrm{O}_{2}$ production at 298 $\mathrm{K}$ under visible light $(\lambda>420 \mathrm{~nm})$ irradiation of $\left[\mathrm{Ru}^{\prime \prime}\left(\mathrm{Me}_{2} \text { phen }\right)_{3}\right]^{2+}(20$ $\mu \mathrm{M})$ in the presence of $\mathrm{Sc}^{3+}(100 \mathrm{mM})$ in $\mathrm{O}_{2}$-saturated $\mathrm{H}_{2} \mathrm{O}(3.0 \mathrm{~mL}$, $\left.\left[\mathrm{O}_{2}\right]=1.2 \mathrm{mM}\right)$ containing $\left[\operatorname{lr}(\mathrm{Cp} *)\left(\mathrm{H}_{2} \mathrm{O}\right)_{3}\right]^{2+}(100 \mu \mathrm{M})$ (red circles). Blue squares are the time course of $\mathrm{H}_{2} \mathrm{O}_{2}$ production expected from the amount of evolved $\mathrm{CO}_{2}$ based on eqn (3). 


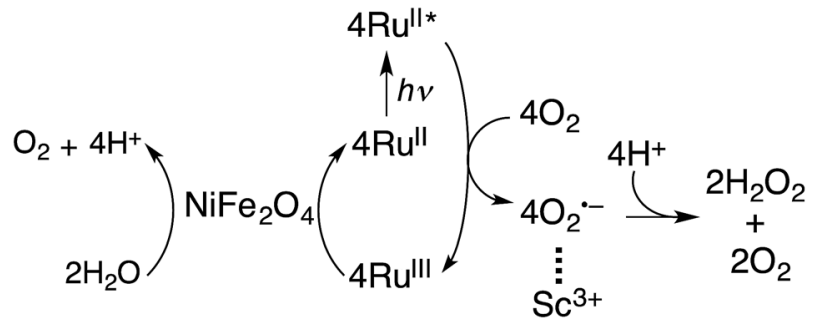

Scheme 1 Overall photocatalytic cycle for $\mathrm{H}_{2} \mathrm{O}_{2}$ production.

$\left[\mathrm{Ru}^{\mathrm{III}}\left(\mathrm{Me}_{2} \text { phen }\right)_{3}\right]^{3+}$ and the decomposition of $\mathrm{H}_{2} \mathrm{O}_{2}$ by $\mathrm{NiFe}_{2} \mathrm{O}_{4}$ are retarded in the presence of $\mathrm{Sc}^{3+}$ (vide supra, Fig. S6 $\dagger$ ). ${ }^{24}$

The photocatalytic production of $\mathrm{H}_{2} \mathrm{O}_{2}$ was performed using $\left[\mathrm{Ru}^{\mathrm{II}}\left(\mathrm{Me}_{2} \text { phen }\right)_{3}\right]^{2+}$ as a photosensitiser and $\mathrm{NiFe}_{2} \mathrm{O}_{4}$ as a WOC (Fig. 7a), which exhibited an induction period at the initial reaction time (black line in Fig. 7b). From the resulting solution, $\mathrm{NiFe}_{2} \mathrm{O}_{4}$ nanoparticles were recovered by centrifugation after 12 $\mathrm{h}$ photoirradiation and reused as WOCs. With the use of recovered $\mathrm{NiFe}_{2} \mathrm{O}_{4}$ as WOCs, the induction period was not observed (blue line in Fig. 7b). The diameter of nanoparticles measured by DLS decreased from $1300 \mathrm{~nm}$ to $620 \mathrm{~nm}$ after $12 \mathrm{~h}$ reaction as shown in Fig. 7c, suggesting that the induction period originates from the decrease in the diameter during the reaction.

In order to determine the conditions necessary for the size change of as-prepared $\mathrm{NiFe}_{2} \mathrm{O}_{4}$, DLS measurements of $\mathrm{NiFe}_{2} \mathrm{O}_{4}$ in an aqueous solution containing $\mathrm{Sc}^{3+}(100 \mathrm{mM})$ were performed under dark (Fig. S7 $\dagger$ ). The diameter of $\mathrm{NiFe}_{2} \mathrm{O}_{4}$ particles decreased to $710 \mathrm{~nm}$, which is in good agreement with the size
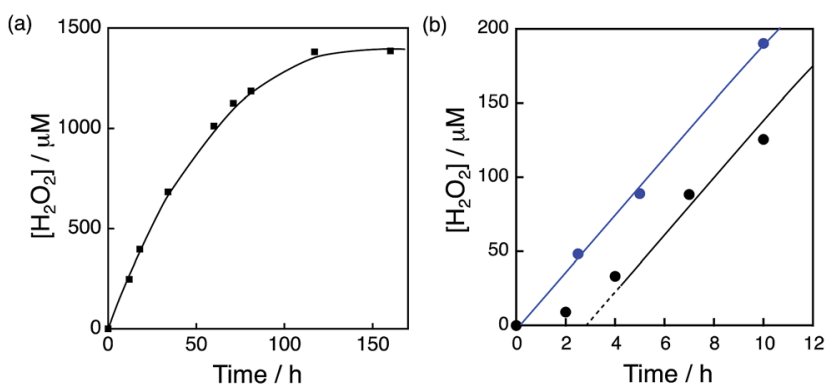

(c)

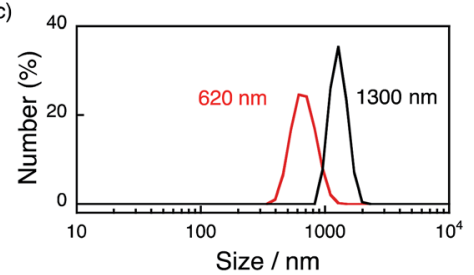

Fig. 7 (a) Time course of $\mathrm{H}_{2} \mathrm{O}_{2}$ production in the presence of $\mathrm{NiFe}_{2} \mathrm{O}_{4}$ $\left(0.17 \mathrm{~g} \mathrm{~L}^{-1}\right)$ and $\mathrm{Sc}^{3+}(100 \mathrm{mM})$ under visible light irradiation $(\lambda>420$ $\mathrm{nm})$ of $\left[\mathrm{Ru}^{\prime \prime}\left(\mathrm{Me}_{2} \text { phen }\right)_{3}\right]^{2+}(200 \mu \mathrm{M})$ in $\mathrm{O}_{2}$-saturated $\mathrm{H}_{2} \mathrm{O}\left(3.0 \mathrm{~mL},\left[\mathrm{O}_{2}\right]\right.$ $=1.2 \mathrm{mM}$ ). (b) Initial period of the plot in (a) (black) and the time course of $\mathrm{H}_{2} \mathrm{O}_{2}$ production in the presence of $\mathrm{NiFe}_{2} \mathrm{O}_{4}$ recovered from the reaction solution after $12 \mathrm{~h}$ of visible light $(\lambda>420 \mathrm{~nm})$ irradiation under the same conditions as in (a) (blue). (c) Size distributions of $\mathrm{NiFe}_{2} \mathrm{O}_{4}$ particles determined by DLS in the reaction solution before (black) and after (red) $12 \mathrm{~h}$ reaction. observed for the particles in the reaction suspension, although the rate of the size change was significantly reduced to $1 / 20$ of that under photoirradiation. This result indicates that the rate of the size change was accelerated with photoirradiation. Then, the size change of $\mathrm{NiFe}_{2} \mathrm{O}_{4}$ was also examined in an aqueous $\mathrm{HNO}_{3}(1.0 \mathrm{M}$ ) solution (Fig. S8 $\dagger$ ) because $\mathrm{Fe}$ and $\mathrm{Ni}$ ions can be soluble in highly acidic solutions. However, the deceleration of the rate of the size change was also observed in the $\mathrm{HNO}_{3}$ solution under dark conditions, as the diameter of $\mathrm{NiFe}_{2} \mathrm{O}_{4}$ did not change even after $24 \mathrm{~h}$ under dark conditions (Fig. S9†). These results indicate that the presence of $\mathrm{Sc}^{3+}$ is necessary for the size change, thus, the dependence of the rate of the size change on the concentration of $\mathrm{Sc}^{3+}$ ranging from 0.1 to $100 \mathrm{mM}$ was examined under room light at $353 \mathrm{~K}$. The fastest sizedecreasing rate was observed for an aqueous solution containing $10 \mathrm{mM}$ of Sc${ }^{3+}$ (Fig. S10†). Under these conditions, the size of formed nanoparticles became as small as $91 \mathrm{~nm}$ after $12 \mathrm{~h}$ (Fig. 8).

The nanoparticles were characterised by powder XRD to confirm that they kept the ferrite structure (Fig. S11†). It was also confirmed that the as-prepared $\mathrm{NiFe}_{2} \mathrm{O}_{4}$ was not dissolved to yield Fe ions. The addition of 1,10-phenanthroline (phen) and the reduced form of $\beta$-nicotinamide adenine dinucleotide disodium salt hydrate (NADH) as a reductant to the supernatant containing $\mathrm{Fe}$ ions produces $\left[\mathrm{Fe}^{\mathrm{II}}(\mathrm{phen})_{3}\right]^{2+}$, which has strong absorption in the visible region $\left(\lambda_{\max }=508 \mathrm{~nm}, \varepsilon=1.1 \times 10^{4}\right.$ $\mathrm{M}^{-1} \mathrm{~cm}^{-1}$ ) and therefore is easily detected (Fig. S12†). It was also supported by the fact that $\mathrm{NiFe}_{2} \mathrm{O}_{4}$ nanoparticles used in the reaction solution were recovered by centrifugation in high

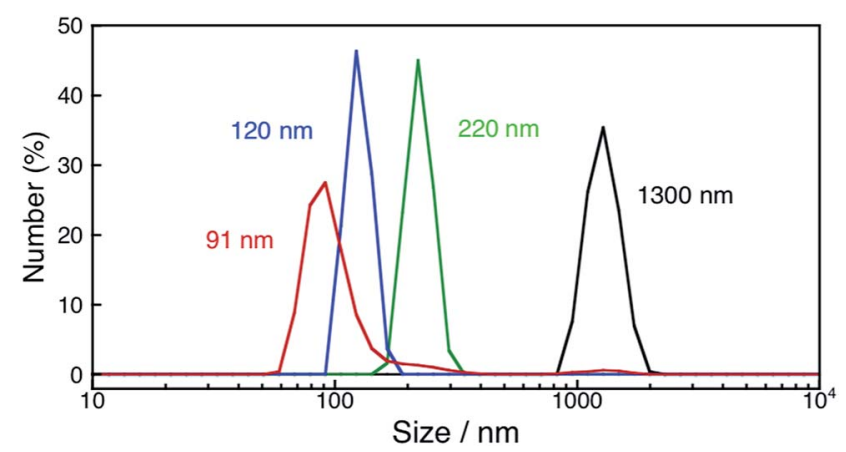

Fig. 8 Size distributions of $\mathrm{NiFe}_{2} \mathrm{O}_{4}$ nanoparticles determined by DLS measurements for an aqueous suspension containing as-prepared $\mathrm{NiFe}_{2} \mathrm{O}_{4}\left(0.17 \mathrm{~g} \mathrm{~L}^{-1}\right)$ (black) and an aqueous suspension containing $\mathrm{NiFe}_{2} \mathrm{O}_{4}$ particles $\left(0.17 \mathrm{~g} \mathrm{~L}^{-1}\right)$ and $\mathrm{Sc}^{3+}(10 \mathrm{mM})$ exposed to room light for $3 \mathrm{~h}$ (green), $6 \mathrm{~h}$ (blue) and $12 \mathrm{~h}$ (red) at $353 \mathrm{~K}$.

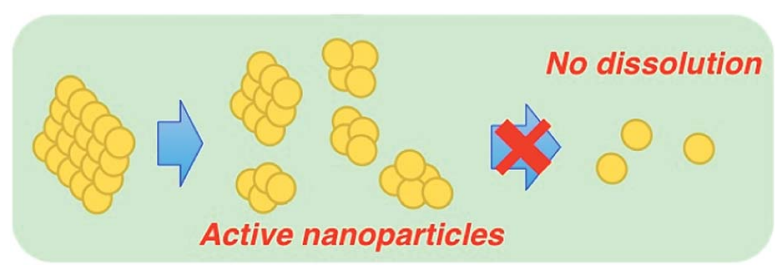

Scheme 2 Mechanism of $\mathrm{NiFe}_{2} \mathrm{O}_{4}$ nanoparticle formation. 

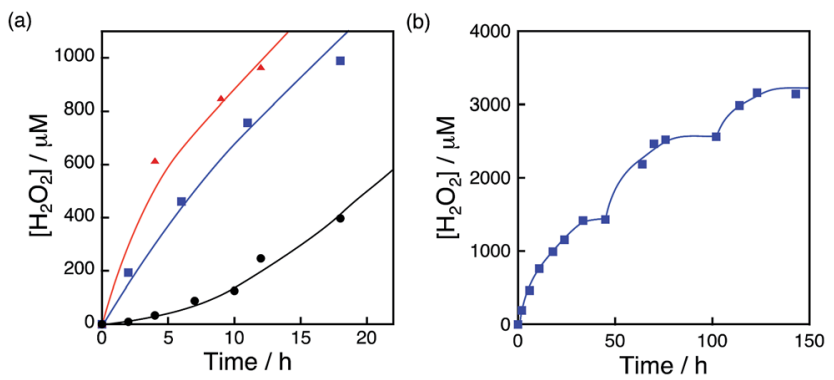

Fig. 9 (a) Time courses of $\mathrm{H}_{2} \mathrm{O}_{2}$ production under visible light irradiation $(\lambda>420 \mathrm{~nm})$ of $\left[\mathrm{Ru}^{\prime \prime}\left(\mathrm{Me}_{2} \text { phen }\right)_{3}\right]^{2+}(200 \mu \mathrm{M})$ in the presence of $\mathrm{Sc}^{3+}(100 \mathrm{mM})$ and $\mathrm{NiFe}_{2} \mathrm{O}_{4}\left(0.17 \mathrm{~g} \mathrm{~L}^{-1}\right)$ with diameters of $1300 \mathrm{~nm}$ (black circles), $120 \mathrm{~nm}$ (blue squares) and $91 \mathrm{~nm}$ (red triangles) in $\mathrm{O}_{2^{-}}$ saturated $\mathrm{H}_{2} \mathrm{O}\left(3.0 \mathrm{~mL},\left[\mathrm{O}_{2}\right]=1.2 \mathrm{mM}\right)$. (b) Time course of $\mathrm{H}_{2} \mathrm{O}_{2}$ production in the presence of $\mathrm{NiFe}_{2} \mathrm{O}_{4}\left(0.17 \mathrm{~g} \mathrm{~L}^{-1}\right)$ and $\mathrm{Sc}^{3+}(100 \mathrm{mM})$ under visible light irradiation $(\lambda>420 \mathrm{~nm})$ of $\left[\mathrm{Ru}^{\prime \prime}\left(\mathrm{Me}_{2} \text { phen }\right)_{3}\right]^{2+}(200$ $\mu \mathrm{M})$ in $\mathrm{O}_{2}$-saturated $\mathrm{H}_{2} \mathrm{O}\left(3.0 \mathrm{~mL},\left[\mathrm{O}_{2}\right]=1.2 \mathrm{mM}\right)$. $\left[\mathrm{Ru}^{\prime \prime}\left(\mathrm{Me}_{2} \text { phen }\right)_{3}\right]^{2+}$ was added twice to the reaction suspension at $50 \mathrm{~h}$ and $100 \mathrm{~h}$ during photoirradiation. The amount of $\left[\mathrm{Ru}^{\prime \prime}\left(\mathrm{Me}_{2} \mathrm{phen}\right)_{3}\right]^{2+}$ added each time at $50 \mathrm{~h}$ and $100 \mathrm{~h}$ to the reaction suspension was calculated in terms of the concentration increase of $200 \mu \mathrm{M}$.

yield (87\%). TEM images of $\mathrm{NiFe}_{2} \mathrm{O}_{4}$ particles manifested that the as-prepared $\mathrm{NiFe}_{2} \mathrm{O}_{4}$ has the form of aggregated smaller primary particles (Fig. S13 $\dagger$ ). The nanoparticles were formed by the dissociation of small particles that consist of a few primary particles as depicted in Scheme 2.

The photocatalytic production of $\mathrm{H}_{2} \mathrm{O}_{2}$ was performed using $\mathrm{NiFe}_{2} \mathrm{O}_{4}$ nanoparticles as the WOCs in the presence of $\left[\mathrm{Ru}^{\mathrm{II}}\left(\mathrm{Me}_{2} \text { phen }\right)_{3}\right]^{2+}$ and $\mathrm{Sc}^{3+}$ under visible light irradiation $(\lambda>$ $420 \mathrm{~nm}$ ) (Fig. 9a and S14 $\dagger$ ). The quantum efficiency determined by using monochromatised light (450 nm) and solar energy conversion efficiency were determined to be $2.7 \%$ and $0.088 \%$, respectively, using $\mathrm{NiFe}_{2} \mathrm{O}_{4}$ nanoparticles with a diameter of

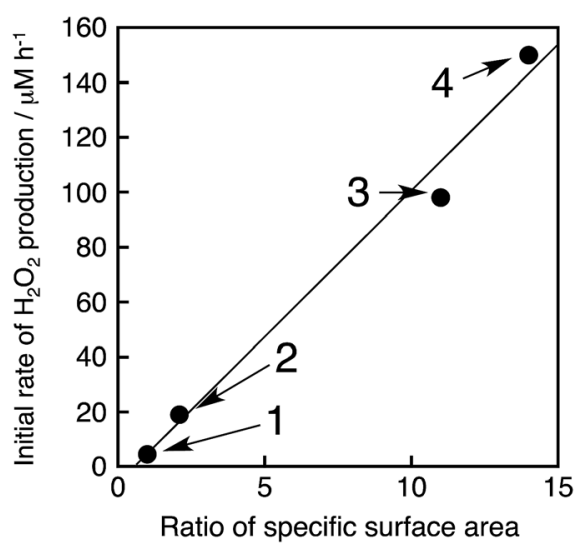

Fig. 10 Plot of initial rates of the photocatalytic $\mathrm{H}_{2} \mathrm{O}_{2}$ production vs. ratios of the specific surface area $(R)$ of $\mathrm{NiFe}_{2} \mathrm{O}_{4}$ particles, where $R=$ (specific surface area of the particles)/(specific surface area of nontreated $\mathrm{NiFe}_{2} \mathrm{O}_{4}$ ). The details of the calculation are described in ESI (Page S23). $\dagger$ The circles denoted as $1-4$ correspond to $\mathrm{NiFe}_{2} \mathrm{O}_{4}$ particles with diameters of $1300 \mathrm{~nm}, 620 \mathrm{~nm}, 120 \mathrm{~nm}$ and $91 \mathrm{~nm}$, respectively. The methods to produce each size of $\mathrm{NiFe}_{2} \mathrm{O}_{4}$ particles and the calculation of initial $\mathrm{H}_{2} \mathrm{O}_{2}$ production rates are described in the caption of Fig. S17. $\dagger$
$90 \mathrm{~nm}$ (Fig. S15 and S16†). To reuse the nanoparticles after $\mathrm{H}_{2} \mathrm{O}_{2}$ production ceased, an aliquot of an aqueous solution containing a high concentration of $\left[\mathrm{Ru}^{\mathrm{II}}\left(\mathrm{Me}_{2} \mathrm{phen}\right)_{3}\right]^{2+}$ was added to the reaction suspension repeatedly, in which the amount of $\left[\mathrm{Ru}^{\mathrm{II}}\left(\mathrm{Me}_{2} \text { phen }\right)_{3}\right]^{2+}$ added to the starting suspension at each run was calculated in terms of the concentration increase of $200 \mu \mathrm{M}$. The concentration of $\mathrm{H}_{2} \mathrm{O}_{2}$ in the resulting suspension increased to be as high as $3.3 \mathrm{mM}$, ensuring the high stability of the nanoparticles as WOCs (Fig. 9b). The initial rate of $\mathrm{H}_{2} \mathrm{O}_{2}$ production was accelerated 22 times and 33 times when using $\mathrm{NiFe}_{2} \mathrm{O}_{4}$ nanoparticles with diameters of $120 \mathrm{~nm}$ and $91 \mathrm{~nm}$, respectively, as compared to the as-prepared $\mathrm{NiFe}_{2} \mathrm{O}_{4}$ with a diameter of $1300 \mathrm{~nm}$ (Fig. 9a). This increase in reactivity could be due to a simple increase in the surface area, therefore, surface areas for nanoparticles were estimated from the respective diameters by eqn (S5) $\dagger$ and compared with respective initial rates of $\mathrm{H}_{2} \mathrm{O}_{2}$ production (Fig. 10). The linear relationship between surface areas and initial rates of $\mathrm{H}_{2} \mathrm{O}_{2}$ production observed in Fig. 10 indicates that the reactivity of each active site for water oxidation in the surface of $\mathrm{NiFe}_{2} \mathrm{O}_{4}$ remains unchanged irrespective of the particle size.

\section{Conclusions}

The reactivity of water oxidation catalysts for the photocatalytic production of $\mathrm{H}_{2} \mathrm{O}_{2}$ from $\mathrm{H}_{2} \mathrm{O}$ and $\mathrm{O}_{2}$ with $\left[\mathrm{Ru}^{\mathrm{II}}\left(\mathrm{Me}_{2} \text { phen }\right)_{3}\right]^{2+}$ and $\mathrm{Sc}^{3+}$ was improved by using $\left[\operatorname{Ir}\left(\mathrm{Cp}^{*}\right)\left(\mathrm{H}_{2} \mathrm{O}\right)_{3}\right]^{2+}$ as a precatalyst, which was converted to $\operatorname{Ir}(\mathrm{OH})_{3}$ nanoparticles during the photocatalytic reaction, as compared with that using $\operatorname{Ir}(\mathrm{OH})_{3}$ nanoparticles derived from $\mathrm{H}_{2} \mathrm{IrCl}_{6}$. The enhanced catalytic reactivity of $\operatorname{Ir}(\mathrm{OH})_{3}$ nanoparticles results from the smaller size of nanoparticles produced in situ as compared with $\operatorname{Ir}(\mathrm{OH})_{3}$ nanoparticles derived from $\mathrm{H}_{2} \mathrm{IrCl}_{6}$. The Cp* ligand of $\left[\operatorname{Ir}\left(\mathrm{Cp}^{*}\right)\left(\mathrm{H}_{2} \mathrm{O}\right)_{3}\right]^{2+}$ was partially oxidised to $\mathrm{CO}_{2}$ during the photocatalytic reaction and remaining organic residues may act as capping reagents to prevent further aggregation of $\operatorname{Ir}(\mathrm{OH})_{3}$ nanoparticles. $\mathrm{NiFe}_{2} \mathrm{O}_{4}$ nanoparticles, which are composed of much more earth abundant metals than Ir, also acted as a water oxidation catalyst for the photocatalytic production of $\mathrm{H}_{2} \mathrm{O}_{2}$ with $\left[\mathrm{Ru}^{\mathrm{II}}\left(\mathrm{Me}_{2} \text { phen }\right)_{3}\right]^{2+}$ in the presence of $\mathrm{Sc}^{3+}$ in water. In this case, the size of $\mathrm{NiFe}_{2} \mathrm{O}_{4}$ nanoparticles decreased during the photocatalytic reaction to increase the catalytic reactivity of water oxidation. Thus, both a bottom-up method starting from a metal complex precatalyst $\left(\left[\operatorname{Ir}\left(\mathrm{Cp}^{*}\right)\left(\mathrm{H}_{2} \mathrm{O}\right)_{3}\right]^{2+}\right)$ to produce $\operatorname{Ir}(\mathrm{OH})_{3}$ nanoparticles with small size and a top-down method starting from as-prepared $\mathrm{NiFe}_{2} \mathrm{O}_{4}$ to obtain smaller $\mathrm{NiFe}_{2} \mathrm{O}_{4}$ nanoparticles provide promising strategies to develop more efficient water oxidation catalysts for photocatalytic production of $\mathrm{H}_{2} \mathrm{O}_{2}$ from $\mathrm{H}_{2} \mathrm{O}$ and $\mathrm{O}_{2}$.

\section{Experimental section}

\section{Materials}

All chemicals commercially available were used without further purification unless otherwise noted. $\mathrm{H}_{2} \mathrm{IrCl}_{6} \cdot n \mathrm{H}_{2} \mathrm{O}(99.99 \%)$ was purchased from Furuya Metal. $\mathrm{RuCl}_{3}(38.220 \mathrm{wt} \% \mathrm{Ru}$ ) was purchased from Tanaka Kikinzoku Kogyo K.K. 4,7-Dimethyl- 
1,10-phenanthroline ( $\mathrm{Me}_{2}$ phen, 98\%), $\mathrm{Ag}_{2} \mathrm{SO}_{4}$ (99.9\%) and $\left(\mathrm{NH}_{4}\right)_{2} \mathrm{SO}_{4}(99.99 \%)$ were supplied by Aldrich Chemicals. Pentamethylcyclopentadiene was obtained from Kanto Chemical Co., Inc. Oxo[5,10,15,20-tetra(4-pyridyl)porphinato]titanium(Iv) ([TiO(tpyp)]) and $\mathrm{NADH}$ were supplied by Tokyo Chemical Industry Co., Ltd. (TCI). $\mathrm{Sc}\left(\mathrm{NO}_{3}\right)_{3} \cdot 4 \mathrm{H}_{2} \mathrm{O}(99.9 \%)$ was supplied by Mitsuwa Chemicals Co., Ltd. Purification of water $(18.2 \mathrm{M} \Omega \mathrm{cm})$ was performed with a Milli-Q system (Millipore, Direct-Q 3 UV). $\left[\operatorname{Ir}\left(\mathrm{Cp}^{*}\right)\left(\mathrm{H}_{2} \mathrm{O}\right)_{3}\right] \mathrm{SO}_{4}$ was prepared by following the reported method. ${ }^{68}$

\section{Synthesis of $\mathrm{NiFe}_{2} \mathrm{O}_{4}$}

$\mathrm{NiFe}_{2} \mathrm{O}_{4}$ was synthesised according to the literature. ${ }^{67,69}$ To an aqueous solution $(24 \mathrm{~mL})$ containing $\mathrm{NiCl}_{2} \cdot 6 \mathrm{H}_{2} \mathrm{O}(2.0 \mathrm{mmol}$, $0.46 \mathrm{~g})$ and $\mathrm{Fe}\left(\mathrm{NO}_{3}\right)_{3} \cdot 9 \mathrm{H}_{2} \mathrm{O}(4.0 \mathrm{mmol}, 1.6 \mathrm{~g})$ was added $\mathrm{KOH}$ solution (2.0 M, $24 \mathrm{~mL})$ with magnetic stirring at room temperature (RT). The mixture was then transferred into a Teflon-lined stainless-steel autoclave of $140 \mathrm{~mL}$ capacity. The sealed tank was heated to and maintained at $160{ }^{\circ} \mathrm{C}$ for $10 \mathrm{~h}$ in an oven and cooled to RT. The resulting brown precipitates were collected by filtration and washed with water and ethanol more than 3 times, and finally dried in an oven at $60{ }^{\circ} \mathrm{C}$ for $10 \mathrm{~h}$.

\section{Formation of $\mathrm{NiFe}_{2} \mathrm{O}_{4}$ nanoparticles}

Typically, an aqueous suspension $(3.0 \mathrm{~mL})$ containing $\mathrm{Sc}\left(\mathrm{NO}_{3}\right)_{3}$ and $\mathrm{NiFe}_{2} \mathrm{O}_{4}(0.50 \mathrm{mg})$ was stirred continuously for $3 \mathrm{~h}, 6 \mathrm{~h}$ or 12 $\mathrm{h}$ at $80{ }^{\circ} \mathrm{C}$ under room light to yield $220 \mathrm{~nm}, 120 \mathrm{~nm}$ and $91 \mathrm{~nm}$ nanoparticles respectively. The suspension was used for the $\mathrm{H}_{2} \mathrm{O}_{2}$ production reaction after the addition of $\left[\mathrm{Ru}^{\mathrm{II}}\left(\mathrm{Me}_{2} \text { phen }\right)_{3}\right]^{2+}$ and $\mathrm{Sc}\left(\mathrm{NO}_{3}\right)_{3} \cdot \mathrm{NiFe}_{2} \mathrm{O}_{4}$ nanoparticles used as a sample for powder $\mathrm{XRD}$ measurements were prepared by immersing as-prepared $\mathrm{NiFe}_{2} \mathrm{O}_{4}(5.1 \mathrm{mg})$ in an aqueous solution $(31 \mathrm{~mL})$ of $\mathrm{Sc}\left(\mathrm{NO}_{3}\right)_{3}$ for $12 \mathrm{~h}$. The resulting powder was collected by centrifugation and washed with water 3 times. The yield of $\mathrm{NiFe}_{2} \mathrm{O}_{4}$ nanoparticles was $87 \%$.

\section{Quantitative measurements of $\mathrm{Fe}^{\mathrm{II}}$ and $\mathrm{Fe}^{\mathrm{III}}$ ions}

An aqueous suspension containing as-prepared $\mathrm{NiFe}_{2} \mathrm{O}_{4}$ and $\mathrm{Sc}\left(\mathrm{NO}_{3}\right)_{3}$ was stirred at $80{ }^{\circ} \mathrm{C}$ for $12 \mathrm{~h}$ for the formation of active $\mathrm{NiFe}_{2} \mathrm{O}_{4}$ nanoparticles as discussed in the previous paragraph. After the formation of $\mathrm{NiFe}_{2} \mathrm{O}_{4}$ nanoparticles, the supernatant of the suspension was examined for the presence of $\mathrm{Fe}^{\mathrm{II}}$ or $\mathrm{Fe}^{\mathrm{III}}$ ions. The filtered supernatant was diluted by water so that the solution may contain $300 \mu \mathrm{M}$ of $\mathrm{Fe}$ ions if $\mathrm{NiFe}_{2} \mathrm{O}_{4}$ was dissolved completely. UV-Vis spectra were measured using a Hewlett Packard 8453 diode array spectrometer for the diluted supernatant in both the presence of 1,10-phenanthroline (phen) $(4.5 \mathrm{mM})$, and in the presence of phen $(4.5 \mathrm{mM})$ and NADH $(1.5 \mathrm{mM})$ to reduce $\mathrm{Fe}^{\mathrm{III}}$ that may have formed. Measured UV-Vis spectra were compared with the UV-Vis spectra of $\left[\mathrm{Fe}^{\mathrm{II}}(\mathrm{phen})_{3}\right]_{3}{ }^{2+}(100 \mu \mathrm{M})$.

\section{Photocatalytic reactions}

$\left[\operatorname{Ir}\left(\mathrm{Cp}^{*}\right)\left(\mathrm{H}_{2} \mathrm{O}\right)_{3}\right] \mathrm{SO}_{4}$ or $\mathrm{NiFe}_{2} \mathrm{O}_{4}$ was introduced into distilled water $(3.0 \mathrm{~mL})$ containing $\left[\mathrm{Ru}^{\mathrm{II}}\left(\mathrm{Me}_{2} \text { phen }\right)_{3}\right] \mathrm{SO}_{4}$ and $\mathrm{Sc}\left(\mathrm{NO}_{3}\right)_{3}$ in a quartz cuvette with a light path length of $1.0 \mathrm{~cm}$. The solution was bubbled with oxygen gas for $\sim 30$ min. The solution containing photocatalyst was irradiated with a xenon lamp (USHIO Optical Modulex SX-UID 501XAMQ) through a cut-off filter (Asahi Techno Glass L42) transmitting $\lambda>420 \mathrm{~nm}$ at room temperature.

\section{Quantification of produced $\mathrm{H}_{2} \mathrm{O}_{2}$}

From spectroscopic titration with an acidic solution of the $\left[\mathrm{TiO}\left(\mathrm{tpypH}_{4}\right)\right]^{4+}$ complex (Ti-TPyP reagent), the amount of produced $\mathrm{H}_{2} \mathrm{O}_{2}$ was determined. ${ }^{70}$ The [TiO(tpyp)] complex (34 $\mathrm{mg}$ ) was dissolved in $1.0 \mathrm{~L}$ of $50 \mathrm{mM}$ hydrochloric acid and the solution was used as a Ti-TPyP reagent. An aliquot (e.g., $100 \mu \mathrm{L})$ of the reaction solution was diluted with water and $0.25 \mathrm{~mL}$ of the sample solution was mixed with $0.25 \mathrm{~mL}$ of $4.8 \mathrm{M}$ perchloric acid and $0.25 \mathrm{~mL}$ of Ti-TPyP reagent. After $5 \mathrm{~min}$ at room temperature, the mixture was diluted to $2.5 \mathrm{~mL}$ with water and used for the spectroscopic measurement. The absorbance at $\lambda=$ $434 \mathrm{~nm}$ was measured by using a Hewlett Packard 8453 diode array spectrometer $\left(A_{\mathrm{S}}\right)$. In a similar manner, a blank solution was prepared by adding distilled water in place of the sample solution in the same volume with its absorbance designated as $A_{\mathrm{B}}$. The difference in absorbance was determined by following the equation: $\Delta A_{434}=A_{\mathrm{B}}-A_{\mathrm{S}}$. Based on $\Delta A_{434}$ and the volume of the solution, the amount of hydrogen peroxide was determined according to the literature. ${ }^{70}$

\section{Determination of the quantum yield}

Quantum yields (QYs) of the photocatalytic production of hydrogen peroxide $(\Phi)$ were determined under irradiation of monochromatised light using a Shimadzu spectrofluorophotometer (RF-5300 PC) through a monochromator transmitting $\lambda=450 \mathrm{~nm}$, and estimated as

$$
\text { QY }(\%)=(2 \times R / I) \times 100
$$

where $R\left(\mathrm{~mol} \mathrm{~s}^{-1}\right)$ and $I$ (einstein $\mathrm{s}^{-1}$ ) represent the $\mathrm{H}_{2} \mathrm{O}_{2}$ production rate and the light intensity, respectively. Two photons are required for the electronic transition of the $\left[\mathrm{Ru}^{\mathrm{II}}\left(\mathrm{Me}_{2} \text { phen }\right)_{3}\right]^{2+}$ photosensitiser in order to produce hydrogen peroxide through two-electron reduction of one molecule of oxygen. When all of the photons are fully utilized to produce hydrogen peroxide, the QY reaches $100 \%$. Therefore, the coefficient of the right-hand side in eqn (4) is 2 for this photocatalytic system. The total number of incident photons was measured by a standard method using an actinometer and potassium ferrioxalate, $\mathrm{K}_{3}\left[\mathrm{Fe}^{\mathrm{III}}\left(\mathrm{C}_{2} \mathrm{O}_{4}\right)\right]_{3}$, in $\mathrm{H}_{2} \mathrm{O}$ at room temperature under photoirradiation using a Shimadzu spectrofluorophotometer (RF-5300 PC) through a monochromator transmitting $\lambda=450$ $\mathrm{nm}$ (slit width of $5.0 \mathrm{~mm}$ ) at room temperature. For the same quartz cuvette with a light path length of $1.0 \mathrm{~cm}$ with $3.0 \mathrm{~mL}$ solution as used in the production of hydrogen peroxide experiments, the rate of photon flux of the incident light $(I)$ was determined to be $7.40 \times 10^{-10}$ einstein $\mathrm{s}^{-1}$. 


\section{Quantification of evolved $\mathrm{CO}_{2}$}

$\left[\operatorname{Ir}\left(\mathrm{Cp}^{*}\right)\left(\mathrm{H}_{2} \mathrm{O}\right)_{3}\right] \mathrm{SO}_{4}(100 \mu \mathrm{M})$ was added to distilled water (3.0 $\mathrm{mL})$ containing $\left[\mathrm{Ru}^{\mathrm{II}}\left(\mathrm{Me}_{2} \text { phen }\right)_{3}\right] \mathrm{SO}_{4}(20 \mu \mathrm{M})$ and $\mathrm{Sc}\left(\mathrm{NO}_{3}\right)_{3}(100$ $\mathrm{mM}$ ) in a quartz cuvette (light path length $=1.0 \mathrm{~cm}$ ). The solution was saturated by bubbling with oxygen gas for $\sim 30$ min. The photocatalyst was irradiated with a xenon lamp (USHIO Optical Modulex SX-UID 501XAMQ) through a cut-off filter (Asahi Techno Glass L42) transmitting $\lambda>420 \mathrm{~nm}$ at room temperature. The amount of evolved $\mathrm{CO}_{2}$ was determined by using a Shimadzu GC-14B gas chromatograph $\left(\mathrm{N}_{2}\right.$ carrier, active carbon with a particle size of $60-80$ mesh at $80{ }^{\circ} \mathrm{C}$ ) equipped with a TCD detector.

\section{Characterisation of particles}

Transmission electron microscopy (TEM) images of iridium hydroxide and nickel ferrite, which were mounted on a copper microgrid coated with elastic carbon, were observed using a JEOL JEM-2100 operating at $200 \mathrm{kV}$. Dynamic light scattering (DLS) data were obtained using a Zeta Sizer Nano ZS (Malvern Instruments Ltd., USA). Powder X-ray diffraction (XRD) patterns were recorded with a Rigaku MiniFlex 600 X-ray diffractometer. X-ray photoelectron spectra (XPS) were obtained with an ULVAC-PHI ESCA5600 X-ray photoelectron spectrophotometer. The incident radiation was the $\mathrm{Mg} \mathrm{K} \alpha \mathrm{X}$-ray $(1253.6 \mathrm{eV})$ at $400 \mathrm{~W}$ and the charge neutralizer was turned on for acquisition. The binding energy of each element was corrected by the $\mathrm{C} 1 \mathrm{~s}$ peak $(284.8 \mathrm{eV})$ from residual carbon.

\section{Acknowledgements}

This work was supported by ALCA (to S.F.) and SENTAN (to T.S. and S.F.) projects from JST, Japan and Grants-in-Aid (nos 24350069 and 25600025 to Y.Y. and 24550077 to T.S.) for Scientific Research from Japan Society for the Promotion of Science (JSPS). D.H. gratefully acknowledges the support from JSPS by Grant-in-Aid for JSPS fellowship for young scientists. We sincerely acknowledge the Research Centre for Ultra-Precision Science \& Technology, Osaka University for TEM measurements.

\section{Notes and references}

1 J. A. Herron, J. Kim, A. A. Upadhye, G. W. Huber and C. T. Maravelias, Energy Environ. Sci., 2015, 8, 126.

2 J. R. McKone, N. S. Lewis and H. B. Gray, Chem. Mater., 2014, 26, 407.

3 T. A. Faunce, W. Lubitz, A. W. Rutherford, D. MacFarlane, G. F. Moore, P. Yang, D. G. Nocera, T. A. Moore, D. H. Gregory, S. Fukuzumi, K. B. Yoon, F. A. Armstrong, M. R. Wasielewski and S. Styring, Energy Environ. Sci., 2013, $6,695$.

4 S. Fukuzumi, D. Hong and Y. Yamada, J. Phys. Chem. Lett., 2013, 4, 3458.

5 S. Fukuzumi and Y. Yamada, ChemSusChem, 2013, 6, 1834. 6 J. M. Thomas, Energy Environ. Sci., 2014, 7, 19.
7 Hydrogen as a Future Energy Carrier, ed. A. Züttel, A. Borgschulte and L. Schlapbach, Wiley-VCH, Weinheim, 2008.

8 Q. Jia, A. Iwase and A. Kudo, Chem. Sci., 2014, 5, 1513.

9 M. G. Walter, E. L. Warren, J. R. McKone, S. W. Boettcher, Q. Mi, E. A. Santori and N. S. Lewis, Chem. Rev., 2010, 110, 6446.

10 K. Maeda and K. Domen, J. Phys. Chem. Lett., 2010, 1, 2655.

11 X. Chen, S. Shen, L. Guo and S. S. Mao, Chem. Rev., 2010, 110, 6503.

12 K. Maeda, K. Teramura, D. Lu, T. Takata, N. Saito, Y. Inoue and K. Domen, Nature, 2006, 440, 295.

13 M. D. Symes and L. Cronin, Nat. Chem., 2013, 5, 403.

14 S. Fukuzumi and T. Suenobu, Dalton Trans., 2013, 18.

15 Y. Maenaka, T. Suenobu and S. Fukuzumi, Energy Environ. Sci., 2012, 5, 7360.

16 S. Fukuzumi, Y. Yamada and K. D. Karlin, Electrochim. Acta, 2012, 82, 493.

17 S. Fukuzumi and Y. Yamada, Aust. J. Chem., 2014, 67, 354.

18 Y. Yamada, M. Yoneda and S. Fukuzumi, Inorg. Chem., 2014, 53, 1272.

19 S. Yamazaki, Z. Siroma, H. Senoh, T. Ioroi, N. Fujiwara and K. Yasuda, J. Power Sources, 2008, 178, 20.

20 S. A. M. Shaegh, N.-T. Nguyen, S. M. M. Ehteshami and S. H. Chan, Energy Environ. Sci., 2012, 5, 8225.

21 F. Yang, K. Cheng, X. Xiao, J. Yin, G. Wang and D. Cao, J. Power Sources, 2014, 245, 89.

22 Y. Yamada, M. Yoneda and S. Fukuzumi, Chem.-Eur. J., 2013, 19, 11733.

23 Y. Yamada, Y. Fukunishi, S. Yamazaki and S. Fukuzumi, Chem. Commun., 2010, 46, 7334.

24 S. Kato, J. Jung, T. Suenobu and S. Fukuzumi, Energy Environ. Sci., 2013, 6, 3756.

25 C. J. Gagliardi, A. K. Vannucci, J. J. Concepcion, Z. Chen and T. J. Meyer, Energy Environ. Sci., 2012, 5, 7704.

26 D. J. Wasylenko, R. D. Palmer and C. P. Berlinguette, Chem. Commun., 2013, 49, 218.

27 X. Liu and F. Wang, Coord. Chem. Rev., 2012, 256, 1115.

28 R. Cao, W. Lai and P. Du, Energy Environ. Sci., 2012, 5, 8134. 29 A. Singh and L. Spiccia, Coord. Chem. Rev., 2013, 257, 2607. 30 C. W. Cady, R. H. Crabtree and G. W. Brudvig, Coord. Chem. Rev., 2008, 252, 444.

31 M.-T. Zhang, Z. Chen, P. Kang and T. J. Meyer, J. Am. Chem. Soc., 2013, 135, 2048.

32 Y. Jiang, F. Li, B. Zhang, X. Li, X. Wang, F. Huang and L. Sun, Angew. Chem., Int. Ed., 2013, 52, 3398.

33 M. Murakami, D. Hong, T. Suenobu and S. Fukuzumi, J. Am. Chem. Soc., 2011, 133, 11605.

34 Q. S. Yin, J. M. Tan, C. Besson, Y. V. Geletii, D. G. Musaev, A. E. Kuznetsov, Z. Luo, K. I. Hardcastle and C. L. Hill, Science, 2010, 328, 342.

35 J. L. Fillol, Z. Codolà, I. Garcia-Bosch, L. Gómez, J. J. Pla and M. Costas, Nat. Chem., 2011, 3, 807.

36 D. Hong, S. Mandal, Y. Yamada, Y.-M. Lee, W. Nam, A. Llobet and S. Fukuzumi, Inorg. Chem., 2013, 52, 9522.

37 G. Chen, L. Chen, S.-M. Ng, W.-L. Man and T.-C. Lau, Angew. Chem., Int. Ed., 2013, 52, 1789. 
38 Y. Liu, S.-M. Ng, S.-M. Yiu, W. W. Y. Lam, X.-G. Wei, K.-C. Lau and T.-C. Lau, Angew. Chem., Int. Ed., 2014, 53, 14468.

39 T. Zhang and W. Lin, Chem. Soc. Rev., 2014, 43, 5982.

40 S. Berardi, S. Drouet, L. Francas, C. Gimbert-Surinach, M. Guttentag, C. Richmond, T. Stoll and A. Llobet, Chem. Soc. Rev., 2014, 43, 7501.

41 M. Hirahara, A. Shoji and M. Yagi, Eur. J. Inorg. Chem., 2014, 595.

42 M. D. Kärkäs, E. V. Johnston, O. Verho and B. Åkermark, Acc. Chem. Res., 2014, 47, 100.

43 A. R. Parent and K. Sakai, ChemSusChem, 2014, 7, 2070.

44 X. Sala, S. Maji, R. Bofill, J. Garcia-Anton, L. Escriche and A. Llobet, Acc. Chem. Res., 2014, 47, 504.

45 J. J. Stracke and R. G. Finke, ACS Catal., 2014, 4, 909.

46 N. D. McDaniel, F. J. Coughlin, L. L. Tinker and S. Bernhard, J. Am. Chem. Soc., 2008, 130, 210.

47 J. F. Hull, D. Balcells, J. D. Blakemore, C. D. Incarvito, O. Eisenstein, G. W. Brudvig and R. H. Crabtree, J. Am. Chem. Soc., 2009, 131, 8730.

48 J. D. Blakemore, N. D. Schley, D. Balcells, J. F. Hull, G. W. Olack, C. D. Incarvito, O. Eisenstein, G. W. Brudvig and R. H. Crabtree, J. Am. Chem. Soc., 2010, 132, 16017.

49 D. G. H. Hetterscheid and J. N. H. Reek, Chem. Commun., 2011, 47, 2712.

50 J. D. Blakemore, N. D. Schley, G. W. Olack, C. D. Incarvito, G. W. Brudvig and R. H. Crabtree, Chem. Sci., 2011, $2,94$.

51 N. D. Schley, J. D. Blackmore, N. K. Subbaiyan, C. D. Incarvito, F. D'Souza, R. H. Crabtree and G. W. Brudvig, J. Am. Chem. Soc., 2011, 133, 10473.

52 D. B. Grotjahn, D. B. Brown, J. K. Martin, D. C. Marelius, M.-C. Abadjian, H. N. Tran, G. Kalyuzhny, K. S. Vecchio, Z. G. Specht, S. A. Cortes-Llamas, V. Miranda-Soto, C. van Niekerk, C. E. Moore and A. L. Rheingold, J. Am. Chem. Soc., 2011, 133, 19024.
53 U. Hintermair, S. W. Sheehan, A. R. Parent, D. H. Ess, D. T. Richens, P. H. Vaccaro, G. W. Brudvig and R. H. Crabtree, J. Am. Chem. Soc., 2013, 135, 10837.

54 D. Hong, M. Murakami, Y. Yamada and S. Fukuzumi, Energy Environ. Sci., 2012, 5, 5708.

55 G. S. Nahor, P. Hapiot, P. Neta and A. Harriman, J. Phys. Chem., 1991, 95, 616.

56 T. Nakagawa, N. S. Bjorge and R. W. Murray, J. Am. Chem. Soc., 2009, 131, 15578.

57 Y. Zhao, E. A. Hernandez-Pagan, N. M. Vargas-Barbosa, J. L. Dysart and T. E. Mallouk, J. Phys. Chem. Lett., 2011, 2, 402.

58 A. Harriman, I. J. Pickering, J. M. Thomas and P. A. Christensen, J. Chem. Soc., Faraday Trans. 1, 1988, 84, 2795.

59 F. Jiao and H. Frei, Energy Environ. Sci., 2010, 3, 1018.

60 N. D. Morris and T. E. Mallouk, J. Am. Chem. Soc., 2002, 124, 11114.

61 S. Fukuzumi and D. Hong, Eur. J. Inorg. Chem., 2014, 4, 645. 62 G. Q. Wei, Y. X. Wang, C. D. Huang, Q. J. Gao, Z. T. Wang and L. Xu, Int. J. Hydrogen Energy, 2010, 35, 3951.

63 M. W. Kanan and D. G. Nocera, Science, 2008, 321, 1072.

64 D. J. Wasylenko, R. D. Palmer, E. Schott and C. P. Berlinguette, Chem. Commun., 2012, 48, 2107.

65 M. Hara, K. Asami, K. Hashimoto and T. Masumoto, Electrochim. Acta, 1983, 28, 1073.

66 H. Y. Hall and P. M. A. Sherwood, J. Chem. Soc., Faraday Trans. 1, 1984, 80, 135.

67 D. Hong, Y. Yamada, T. Nagatomi, Y. Takai and S. Fukuzumi, J. Am. Chem. Soc., 2012, 134, 19572.

68 S. Ogo, N. Makihara and Y. Watanabe, Organometallics, 1999, 18, 5470 .

69 Y. Cheng, Y. Zheng, Y. Wang, F. Bao and Y. J. Qin, Solid State Chem., 2005, 178, 2394.

70 C. Matsubara, N. Kawamoto and K. Takamura, Analyst, 1992, 117, 1781. 